\title{
Movement of fluorescent dyes Lucifer Yellow (LYCH) and carboxyfluorescein (CF) in Medicago truncatula Gaertn. roots and root nodules
}

\author{
Magdalena Bederska • Wojciech Borucki • Ewa Znojek
}

Received: 8 September 2012 / Accepted: 2 January 2013 / Published online: 15 January 2013

(C) The Author(s) 2013. This article is published with open access at Springerlink.com

\begin{abstract}
Lucifer Yellow (LYCH) and carboxyfluorescein (CF) served in Medicago truncatula roots and root nodules as the markers of apoplastic and symplastic transport, respectively. The aim of this study was to understand better the water and photoassimilate translocation pathways to and within nodules. The present study shows that in damaged roots LYCH moves apoplastically through the vascular elements but it was not detected within the nodule vascular bundles. In intact roots, the outer cortex was strongly labeled but the dye was not present in the interior of intact root nodules. The inwards movement of LYCH was halted in the endodermis. When the dye was introduced into a damaged nodule by infiltration, it spread only in the cell walls and the intercellular spaces up to the inner cortex. Our research showed that in addition to the outer cortex, the inner tissue containing bacteroid-infected cells is also an apoplastic domain. Our results are consistent with the hypothesis that nodules do not receive water from the xylem but get it and photoassimilates from phloem. A comparison between using LYCH and LYCH followed by glutaraldehyde fixation indicates that glutaraldehyde is responsible for fluorescence of some organelles within root nodule cells. The influence of the fixation on nodule fluorescence has not been reported before but must be taken into consideration to avoid errors. An attempt was made to follow carboxyfluorescein $(6(5) \mathrm{CF})$ translocation from leaflets into roots and root nodules. In root nodules, CF was present in all or a couple of vascular bundles (VB), vascular endodermis
\end{abstract}

M. Bederska $(\bowtie) \cdot$ W. Borucki $\cdot$ E. Znojek

Faculty of Agriculture and Biology, Department of Botany,

Warsaw University of Life Sciences WULS-SGGW,

159 Nowoursynowska Str,

02-776 Warsaw, Poland

e-mail: magdalena_bederska@sggw.pl and some adjacent cells. The leakage of CF from the VBs was observed, which suggests symplastic continuity between the VBs and the nodule parenchyma. The lack of CF in inner tissue was observed. Therefore, photoassimilate entry to the infected region of nodule must involve an apoplastic pathway.

Keywords Apoplastic and symplastic tracing . Carboxyfluorescein (CF) · Lucifer Yellow (LYCH) · Medicago truncatula $\cdot$ Root nodule $\cdot$ Vascular bundle

\section{Introduction}

The legume plant Medicago truncatula Gaertn. establishes a fully effective symbiosis with the nitrogen-fixing bacteria Sinorhizobium medicae or Sinorhizobium meliloti belonging to the family of Rhizobiaceae (Oldroyd and Geurts 2001, Terpolilli et al. 2008). The development of nodules relies on a continuous molecular dialogue between these two symbionts and employs a complex developmental program involving organogenesis, specific cellular differentiation of host cells and endosymbiotic bacteria, called bacteroids, as well as the specific activation of a large number of plant and bacteria genes. This symbiosis provides the nitrogen source and is based on nutrient exchange. The bacterium provides ammonium from nitrogen fixation to the plant that, in turn, supplies the bacterium with carbohydrates derived from photosynthesis. The symbiosis allows these plants to grow on nitrogen poor soils (Hirsch 1992, Jones et al. 2007).

Root nodules formed by Medicago sp. represent an indeterminate type of nodule. This means that the nodule meristem maintains its activity during the whole growth cycle. As a result of this activity, different histological zones can be distinguished in the fully developed nodule. The meristematic zone occurs in the apical part. The second zone is 
an early symbiotic zone (invasion zone), where cells are penetrated by the infection threads. The adjacent part is young symbiotic tissue, where bacteria are released from the infection threads into the cytosol and symbiosomes are formed. Next to this part, there is a transitional zone with a lot of starch stored in cells. The biggest volume of the nodule is a symbiotic zone that consists of infected and uninfected cells. Finally, there is a senescent zone, where symbionts degenerate (Vasse et al. 1990, Hirsch 1992, Stougaard 2000, Vernie et al. 2008). The peripheral tissues that surround the infected tissue consist of three different cell layers: (1) outer cortex, (2) nodule endodermis and (3) inner cortex often called 'nodule parenchyma' (Brown and Walsh 1994).

In nodules, conversion of dinitrogen gas into ammonia requires a large quantity of energy from aerobic respiration. Nitrogenase, a key enzyme in nitrogen fixation, is sensitive to atmospheric concentration of oxygen. An oxygen diffusion barrier, which regulates the rate of $\mathrm{O}_{2}$ entry to the nodule interior and participates in nitrogenase protection from damage, is supposed to operate in the nodule parenchyma. Structurally, this barrier is strongly dependent on the nodule cortical anatomy, which differs among species (Brown and Walsh 1994, Sujkowska et al. 2011). The inner and outer cortex are separated by the nodule endodermis, defined by Frazer (1942) as 'common endodermis', consisting of one cell layer, and now usually termed 'nodule endodermis'. The nodule endodermis possesses suberin lamellae and never closes at the nodule meristem. The vascular system is located in the inner cortex of the nodule. Each vascular bundle has its own endodermis (Brown and Walsh 1996). Vascular bundles in the inner cortex of the nodule come to a dead end and the flow of solutes is one-way (Guinel 2009).

The effectiveness of nitrogen fixation may depend on the N-feedback mechanism (Schulze 2004). The transportation of water within a nodule may be a factor limiting nitrogen fixation effectiveness because of the need to maintain the balance between export of amides and import of photo assimilates (Streeter 1993, White et al. 2007). There are three possible pathways of movement of water into nodules: (1) bulk flow via xylem vessels or (2) via cell walls and intercellular spaces or (3) symplastic movement of water through phloem and cortex (Streeter 1993).

Determining water movement by means of describing the interactions between the apoplastic and symplastic pathways is laborious but this issue is relevant to photoassimilate transport and solute exchange. Cell wall modifications can partially or completely restrict solute movement. As a result, the apoplast can be divided into regions called the 'apoplastic domains'. The presence of apoplastic domains in root nodules has been affirmed. The cortex of the root nodule provides a high resistance to movement in the apoplast (Fisher and Oparka 1996). Apoplast-symplast solute exchange is extremely important. It plays a role in maintaining constant turgor and thereby takes part in regulation of convective transport. For the symplastic pathway, Complainville et al. (2003) revealed the establishment of a new symplastic field between the root phloem and nodule primordium by using $6(5) \mathrm{CF}$ as a phloem sap tracer. 6(5)CF is widely used as a symplastic mobile phloem sap tracer, which cannot cross the plasma membrane (Pradel et al. 1999, Massou et al. 2000, Ade-Ademilua and Botha 2006). The major transport form of photoassimilated carbon is sucrose (Lemoine 2000). In leaves, sucrose is loaded into sieve elements-companion cells $(\mathrm{SE} / \mathrm{CC})$ and transported to sink organs (Lalonde et al. 2003). Phloem unloading and post-phloem transport of sugars can proceed symplastically via plasmodesmata or apoplastically via transmembrane sugar fluxes (Fisher and Oparka 1996). It is still not clear which kind of pathway, symplastic or apoplastic, is favored in indeterminate root nodules.

Lucifer yellow (FW 457.2) is a membrane-impermeable fluorescent dye, which is frequently used as an apoplastic tracer and fluid-phase endocytosis marker (Oparka and Prior 1988, Oparka 1991, Owen et al. 1991, Baluska et al. 2004). The dye is also aldehyde-fixable because of the free carbohydrazide $(-\mathrm{CH})$ group which allows LYCH to be linked to surrounding biomolecules during aldehyde fixation (Stewart 1981). LYCH was used as an apoplastic dye for root nodules by Brown and Walsh (1996) and Brown et al. (1997).

The focus of this study includes LYCH and 6(5)CF transport in roots and the spreading of the dyes within the nodule. We also examined the use of LYCH with and without glutaraldehye fixation to establish whether fixation may produce artefacts.

\section{Material and methods}

\subsection{Plant material}

Barrel medic (Medicago truncatula Gaertn.) cv Jemalong seeds of were surface sterilized with $1 \%$ sodium hypochloride and germinated on $0.8 \%(\mathrm{w} / \mathrm{v})$ water agar. Young seedlings with straight primary roots, $0.5 \mathrm{~cm}$ long, were selected. Plants were grown in $5 \mathrm{~L}$ pots containing perlite (14-h photoperiod, photon flux density of $300 \mu \mathrm{mol} \mathrm{m} \mathrm{m}^{-2} \mathrm{~s}^{-1}, 22{ }^{\circ} \mathrm{C} / 17{ }^{\circ} \mathrm{C}$ day/night regime, $70 \%$ relative humidity). Seedlings were inoculated with Sinorhizobium medicae WSM 419 suspension 2 days after planting. Growing plants were given nutrients once a week (according to Fahraeus 1957) and distilled water as required. Nodules were processed $42 \mathrm{~d}$ post inoculation. 


\subsection{Apoplastic tracing with Lucifer Yellow}

Root nodules were exposed for $12 \mathrm{~h}$ to $1 \%$ Lucifer Yellow and analyzed without fixation or subjected to a vacuum for two 1-min intervals and fixed overnight into $4 \%$ glutaraldehyde in $50 \mathrm{mM}$ phosphate buffer (as described by Brown et al. 1997). After the treatments, roots and root nodules were washed with distilled water.

Whole root systems or hand-cut transverse and longitudinal sections taken from roots and root nodules using one half of a double-sided razor blade were immersed and mounted in water and analyzed with confocal microscopy. All sections were examined with a Leica TCS SP5 laser scanning confocal inverted microscope using $10 \times, 20 \times$ or $40 \times$ (water/glycerol) objectives after excitation at $405 \mathrm{~nm}$ diode laser. Emission spectrum was between $500 \mathrm{~nm}$ and $550 \mathrm{~nm}$ with maximum $528 \mathrm{~nm}$. Under this wavelength autofluorescence was exhibited by cell walls (blue channel, data not shown) and the presence of LYCH (yellow channel).

\subsection{Symplastic tracing with 6(5)CFDA}

42 days after inoculation the 6(5)carboxyfluoresceine diacetate (6(5)CFDA) was introduced to the abraded surface of the bottom side of the two lowest leaves. The damage was made by rubbing with fine sand-paper. After $12 \mathrm{~h}$, freehand cross and longitudinal sections of nodules were prepared and observed under a confocal laser scanning microscope (CLSM) after excitation at $488 \mathrm{~nm}$, CF emission 500 $566 \mathrm{~nm}$ (green channel).

\subsection{Autofluorescence}

To determine any contribution to emission due to autofluorescence, specimens taken from control and treated plants were also examined at the different wavelengths and gain settings used in this study. The main autofluorescence was detected between $500 \mathrm{~nm}$ and $650 \mathrm{~nm}$ by excitation with $405 \mathrm{~nm}$ diode or $488 \mathrm{~nm}$ argon laser. Overlay of the
Fig. 1 The bright field (a) and CLSM (b-g) photographs of non-fixed tissues. Part of nodulated root system (a). Cross section of control root nodule (b). The uptake of LYCH by untouched root (c) and untouched root nodule $(\mathbf{d}, \mathbf{e}-$ cross section). Damaged root exhibited LYCH fluorescence in xylem elements $(\mathbf{d}, \mathbf{g})$. Cross section of the stele of control root (f). Cross section of root stele treated with $\mathrm{LYCH}(\mathrm{g})$. Abbreviations: IT - inner tissue, OC - outer cortex, VB vascular bundle, $\mathrm{X}$ - xylem vessels, arrow - parts of cells stained with $\mathrm{LYCH}$, double arrow-head - autofluorescence of uninfected cells. Bars represent: A and $C=100 \mu \mathrm{m}, \mathrm{B}$ and $E=200 \mu \mathrm{m}, D=150 \mu \mathrm{m}, \mathrm{F}$ and $G=50 \mu \mathrm{m}$. LYCH fluorescence was observed after excitation at $405 \mathrm{~nm}$, emission spectrum was between $500 \mathrm{~nm}$ and $550 \mathrm{~nm}$
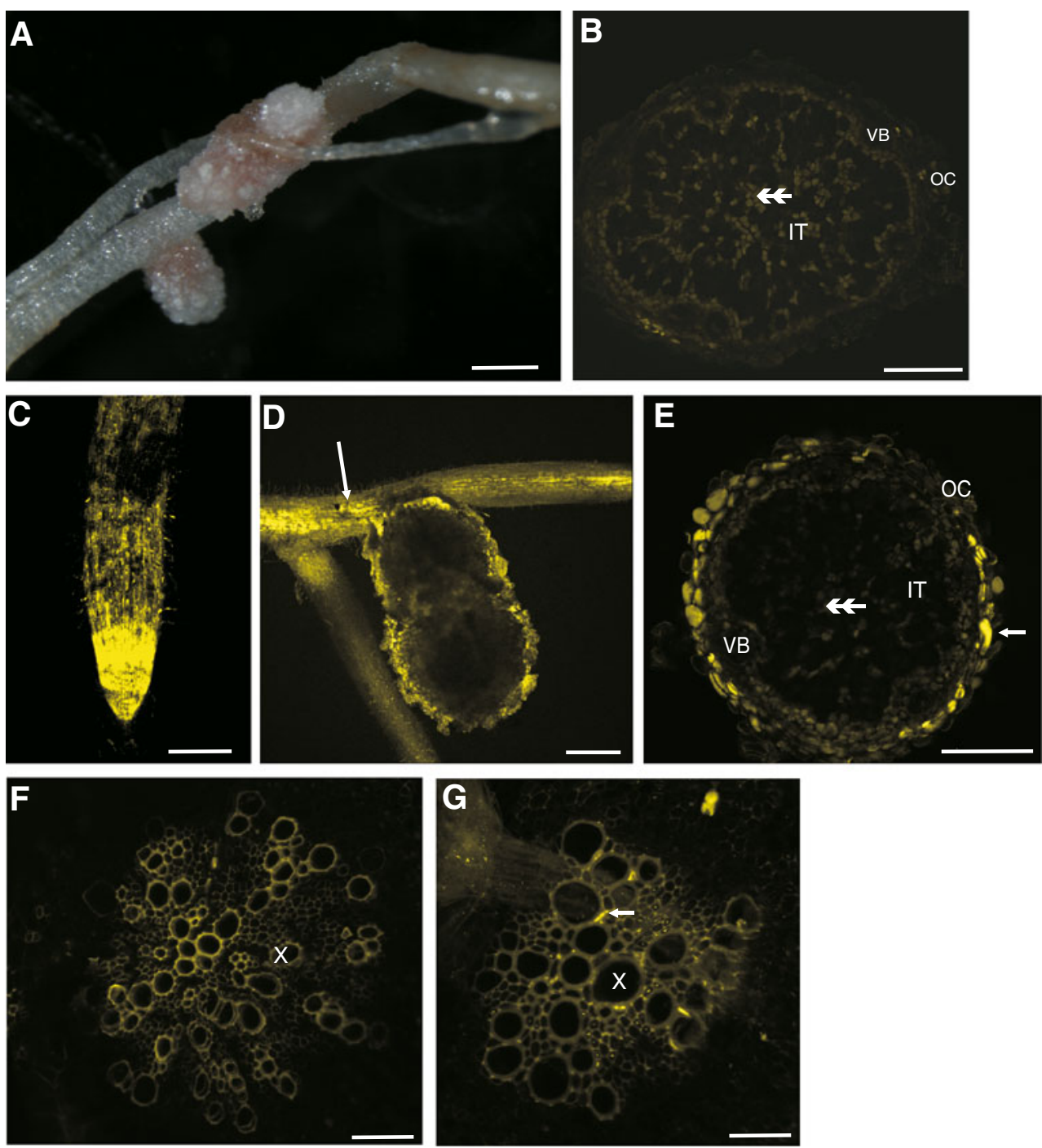
different channels allowed to distinguish between autofluorescence and $\mathrm{LYCH}$ or 6(5)CF fluorescence.

\section{Results}

\subsection{Movement of LYCH in nodulated root system}

In mature Medicago truncatula plants inoculated with strain Sinorhizobium meliloti WSM 419, effective root nodules were established (Fig. 1a). The cross section of the nodule revealed only autofluorescence by uninfected and parenchymal cells (Fig. 1b). The movement of LYCH through roots was studied using a whole, unimpaired root system and in roots that had their tips completely cut off with a razor blade. After submerging undamaged roots in $\mathrm{LYCH}$, fluorescent dye was detected in the root epidermis of young tips (Fig. 1c). When LYCH was infiltrated into a damaged root, the dye seemed to be restricted to the stele (Fig. 1d, g). However, in both cases, no dye was found within the root nodules, not even in their vascular bundles. Only the outer nodule cortex was strongly labeled (Fig. 1e). The dye did not cross the nodule endodermis. Even after $24 \mathrm{~h}$ immersion in $\mathrm{LYCH}$, the dye did not pass beyond the outer cortex (Fig. 1e).

\subsection{Movement of LYCH in damaged root nodules}

Root nodules were damaged by cutting off a part of the nodule consisting of outer cortex and 2-3 layers of inner tissue. This allowed the dye to penetrate all root nodule tissues.
Fig. 2 The CLSM photographs of non-fixed sections. Spreading of LYCH through damaged root nodule $(\mathbf{a}, \mathbf{c}, \mathbf{e})$ with a comparison to a control nodule inner tissue $(\mathbf{b}, \mathbf{d}, \mathbf{e})$. Notice the dye within the cell walls and the lack of fluorescence in the inner cortex cell walls (e). The cells adjacent to the place of cutting are strongly fluorescent (c). The control root nodule exhibits only pale yellow autofluorescence of uninfected cells (b,d, f). Abbreviations:, $\mathrm{CE}-\mathrm{com}-$ mon endodermis, IC - inner cortex, IT - inner tissue, OC outer cortex, VE - vascular endodermis, VB - vascular bundle, arrows - parts of cells stained with $\mathrm{LYCH}$, double arrow-head - autofluorescence of uninfected cells. Bars represent: $A$ and $B=300 \mu \mathrm{m}, \mathrm{C}, \mathrm{D}, \mathrm{E}$ and $F=20 \mu \mathrm{m}$
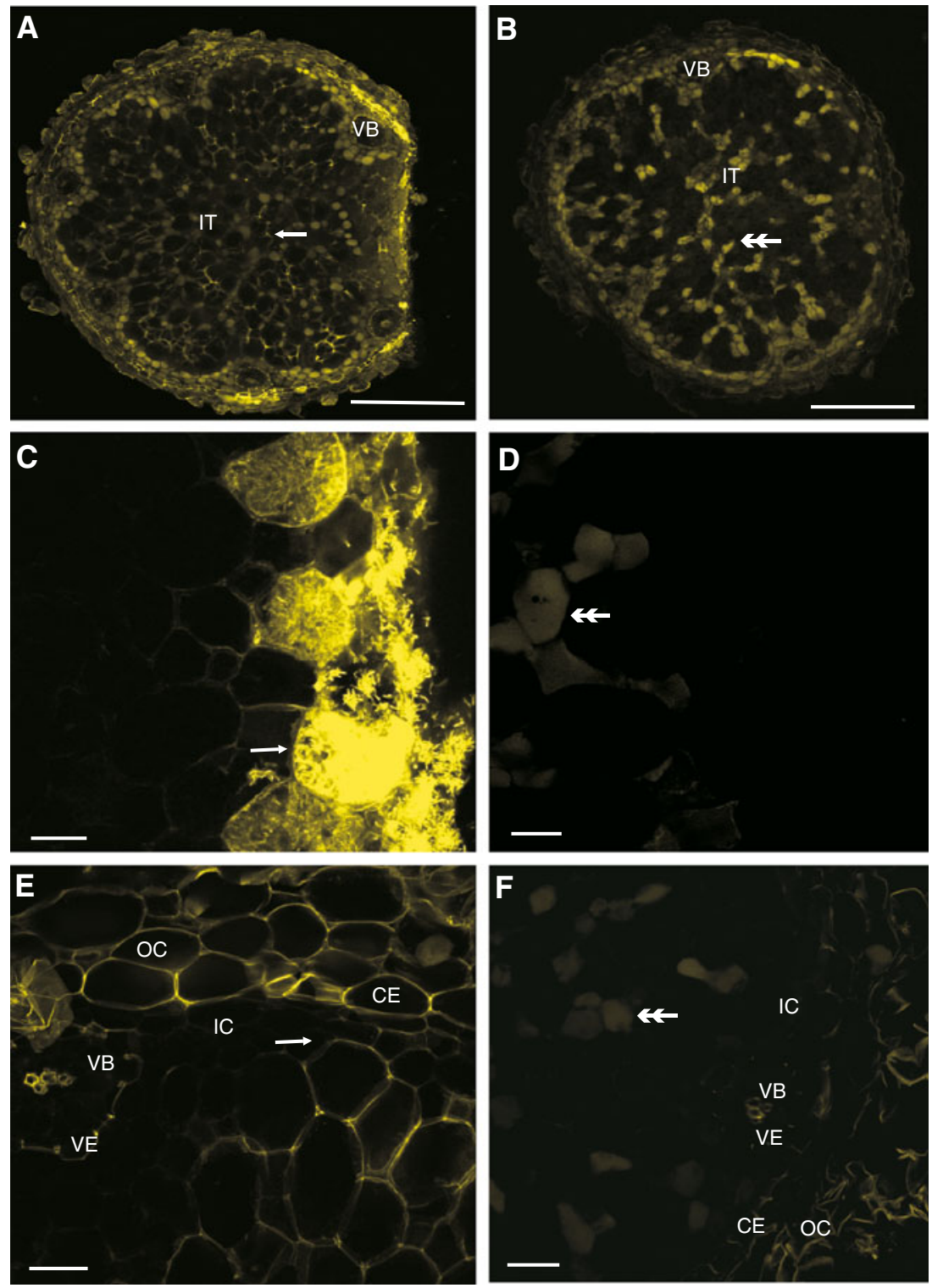
Damaged root nodules were submerged in LYCH solution, sliced manually and observed under CLSM. The penetration of the LYCH dye into root nodules was examined after $12 \mathrm{~h}$ of exposure. The first cell layer at the place of damage was strongly labeled (Fig. 2a, c). In damaged cells, bacteroids fluoresced intensely. Some adjacent cells also exhibited strong LYCH-induced fluorescence. In the undamaged control root nodules, no fluorescence of cell walls was detected (Fig. 2b, d, f), only uninfected cells exhibited pale auofluorescence. However, the further spreading of the dye was restricted to the cell walls and intercellular spaces of the inner tissue (Fig. 2e). The dye penetrated the walls of infected and uninfected cells as well as intercellular spaces. LYCH did not penetrate fully through the nodule. The apoplastic dye infiltrated the nodule only as far as the outside layer of infected cells in the inner tissue. The movement was there impeded (Fig. 2e).
A control nodule not treated with LYCH showed only pale yellow autofluorescence of uninfected cells (Fig. 2f).

\subsection{LYCH staining followed by fixation}

Root nodules of $M$. truncatula were immersed in LYCH and fixed in $4 \%$ glutaralaldehyde according to Brown et al. (1997). We found fluorescence in four cell compartments. Firstly, fluorescence was observed in nuclei (Fig. 3a, c, e). Secondly, infected cells containing bacteroids showed fluorescence (Fig. 3a). Thirdly, some of vacuoles in the infected cells were fluorescent (Fig. 3c). Lastly, the outer cortical cell walls fluoresced intensely (Fig. 3e).

We fixed damaged root nodules with $4 \%$ glutaraldehyde as described above without the addition of LYCH. We observed strong fluorescence in cell walls, nuclei, infected cells cytosol and some vacuoles in both whole and damaged
Fig. 3 The CLSM photographs of non-fixed root nodules stained with $\mathrm{LYCH}(\mathbf{a}, \mathbf{c}, \mathbf{e})$ and the influence of glutaraldehyde fixation on the fluorescence properties of root nodule staining with $\mathrm{LYCH}$ and subsequently fixing in glutaraldehyde $(\mathbf{b}, \mathbf{d}, \mathbf{f})$. Notice fluorescence of the nuclei (arrows in $\mathbf{a}$ vs. $\mathbf{b}, \mathbf{c}$ vs. d, e), the vacuoles (c vs. d), outer cortex (a vs. b, $\mathbf{c}$ vs. $\mathbf{d}, \mathbf{e}$ vs. f) and pericycle of vascular bundle (f). Abbreviations:, CE - common endodermis, IC inner cortex, IT - inner tissue, $\mathrm{M}$ - meristem, $\mathrm{OC}$ - outer cortex, $\mathrm{PC}$ - pericycle cells, UIC uninfected cells, VB - vascular bundle, arrows - parts of cells stained with $\mathrm{LYCH}$, double arrow-head - autofluorescence of uninfected cells. Bars represent: $A$ and $B=60 \mu \mathrm{m}, C=$ $100 \mu \mathrm{m}, \mathrm{D}$ and $E=30 \mu \mathrm{m}, F=$ $200 \mu \mathrm{m}$
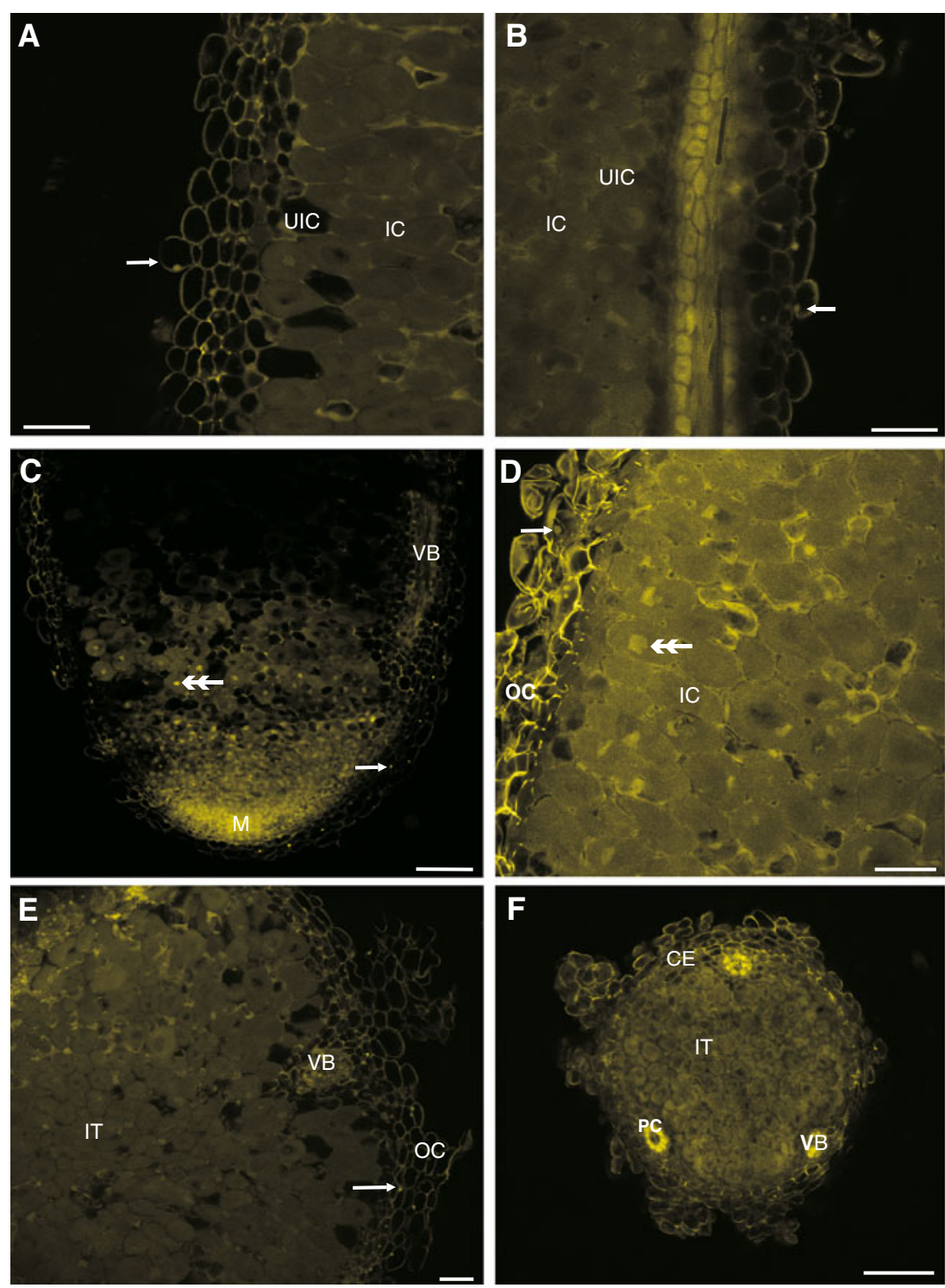
root nodules (Fig. 3b, d, f). In addition, strong fluorescence was exhibited by pericycle cells of the vascular bundles (Fig. 3f). Generally, there was no significant difference between fluorescing components in tissues treated with glutaraldehyde alone and those treated with glutaraldehyde and LYCH.

\subsection{Carboxyfluorescein (CF) translocation}

The tracer was observed firstly in the mesophyll and the vascular system of leaflets (Fig. 4a). Secondly, it appeared in the stem (data not shown) and finally in the main root and some of the lateral roots (Fig. 4b). In root nodules, CF was present in almost all vascular bundles and in the endodermis of vascular bundles as well as the first layer of the nodule parenchyma cells (Fig. 4c, d, e). Control nodules exhibited no fluorescence in the area of vascular bundles (Fig. 4f).

\section{Discussion}

Root nodules formed by $M$. truncatula have a welldeveloped vascular system that guarantees an efficient supply of nutrients from the host and export of nitrogenous products from nodules. Effective nitrogen fixation in nodules depends on the balance between the import of photoassimilates and the export of nitrogenous solutes (Walsh et al. 1989, Streeter 1993, Schulze 2004). It has been hypothesized that some water reaches the nodules via bulk flow from the vascular apoplast through the nodule cortex, but the main water transport into the nodule occurs via the phloem (Streeter 1993).

Fig. 4 The CLSM photographs of non-fixed tissues. Transportation of 6(5)carboxyfluoresceine (6(5)CF) from mesophyll of leaflet (a) into root (b) and root nodule (c, d, e). Notice the fluorescence of vascular bundles (arrows in $\mathbf{d}$, e). The control root nodule exhibits only the pale autofluorescence of uninfected cells (double arrowhead in f). Abbreviations: IT inner tissue, $\mathrm{M}$ - meristem, $\mathrm{PC}$ pericycle cells, $\mathrm{SZ}$ - symbiotic zone, TE - tracheary elements, $\mathrm{VE}$ - vascular endodermis, $\mathrm{VB}$ vascular bundle. 6(5)CF fluorescence was observed after excitation at $488 \mathrm{~nm}$, emission spectrum was between $500 \mathrm{~nm}$ and $566 \mathrm{~nm}$. Bars represent: $A=115 \mu \mathrm{m}, B=$ $250 \mu \mathrm{m}, C=100 \mu \mathrm{m}, D=60 \mu \mathrm{m}$, $E=20 \mu \mathrm{m}, F=150 \mu \mathrm{m}$
Here we present new data related to apoplastic water delivery to nodules using $\mathrm{LYCH}$, a marker for fluid-phase endocytosis and an apoplastic tracer (Fisher 1988, Oparka and Prior 1988, Tucker et al. 1989, Hillmer et al. 1989, 1990, Owen et al. 1991, Baluska et al. 2004). Intact roots took up the dye mainly at the root tips by epidermal cells. This is in accordance with the observations of Oparka and Prior (1988), who proved fluid-phase endocytosis in plants using the uptake of LYCH into intact barley roots.

In damaged roots, LYCH was transported over a long distance in the xylem without reaching the root nodules. On the other hand, when undamaged nodulated roots were submerged in the dye, LYCH diffusion stopped in the nodule outer cortex. These results suggest that $M$. truncatula root nodules are not even partially provided with water from xylem. Furthermore, the nodule endodermis seems to be a barrier for apoplastic transportat of water directly from the soil.

Apoplastic transport in root nodules can be hampered in the nodule or/and vascular endodermis as a result of suberin depositions in radial cell walls (Abd-Alla et al. 2000). In Pisum sativum the use of carboxyfluorescein (CF) revealed that the nodule endodermis halted the diffusion of the dye which therefore accumulated in the outer cortex of the pea root nodules (Kramer et al. 2007, Sujkowska et al. 2011). These results suggest that the nodule endodermis is a barrier for water and solute influx into the nodule. However, Brown and Walsh (1996) indicated that the nodule endodermis (when present) was not able to halt $\mathrm{LYCH}$ infiltration, but diffusion of the dye was blocked within the inner cortex of Trifolium repens root nodules.

Damage to root nodules was employed to facilitate dye penetration. Nodule tissues were then analyzed to determine
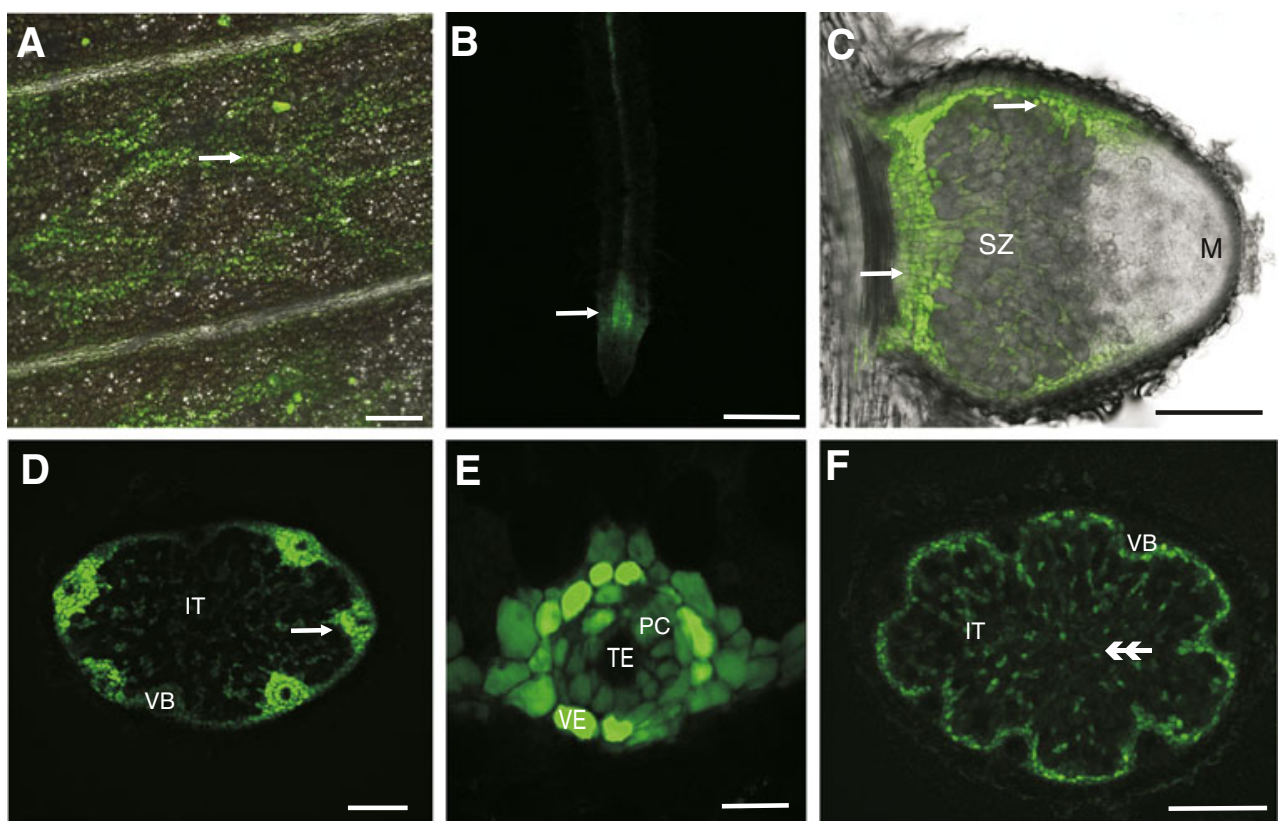
the possible apoplastic movement of the dye. LYCH spread apoplastically within the inner tissue to the inner cortex, which suggests that the inner tissue is an apoplastic domain that is isolated from the nodule cortex. According to Parsons and Day (1990), the inner cortex serves as a gas diffusion barrier and is characterized by low permeability for water.

A comparison of LYCH translocation in unfixed and fixed nodules led to the conclusion that glutaraldehyde fixation may result in nonspecific fluorescence of the cytosol, vacuoles and nuclei. Therefore, the use of LYCH with this fixative may produce artefacts and cannot be recommended for the study of water movement within nodules.

$\mathrm{CF}$ translocation was monitored to follow the possible pathways of sucrose transportation from the leaflets to the inner tissue. Complainville et al. (2003) reported that there is a plasmodesmatal connection between root phloem and the cells of nodule primordia. This was indicated by the presence of $\mathrm{CF}$ in the root pericycle, the root cortical cells, and the cells of the nodule primordium in Medicago sativa. Further evidence was the fluorescence of GFP expressed under control of the phloem companion cell-specific AtSUC2 promoter in nodule primordia, as well as in the meristem and in the invasion zone of the inner tissue of mature nodules of $M$. truncatula. Our experiments confirmed that CF was translocated in sieve elements. Then, CF spread symplastically in the pericycle and endodermis of the nodule vascular bundles, as well as in the first layer of the nodule parenchyma cells that surrounded the vascular bundles. However, no CF fluorescence was detected in the nodule meristem and the invasion zone. Root nodules represent strong carbon sinks and the highest input of photoassimilates is thought to be directed to infected cells. Complainville et al. (2003) performed their experiment using two species $-M$. sativa and $M$. truncatula, both inoculated with Sinorhizobium meliloti strain Sm41. Some of the sections were also fixed ( $3 \%$ paraforlmadehyde). Some of their results are not in accordance with those from the present study and it can be linked with different growth conditions and bacteria strains suitability. Recent information indicates that symplastic communication or isolation of groups of cells may be crucial for their differentiation during the developmental stages. Plasmodesmal connections play role in such regulation by controlling the flux of proteins and mRNAs/miRNAs (Marzec and Kurczynska 2008).

Based on our results, it may be assumed that sucrose delivered to the nodule via the phloem is distributed symplastically as far as the outer layer of the nodule parenchyma. The vascular bundles and surrounding parenchyma cells form a symplastic field. Further translocation of sucrose within the nodule is probably apoplastic. These results indicate that parenchyma cells that surrounded VBs play a crucial role in the distribution of photoassimilates in nodules. This is very interesting in terms of the postulated role of the nodule parenchyma cells in the regulation of nodule permeability to oxygen (Sujkowska et al. 2011 and literature cited therein). Apoplastic spreading of sucrose within the inner parenchyma might, for instance, influence cell turgor and metabolic activity, two factors of possibly great importance to the functioning of the oxygen diffusion barrier. Parenchyma cells adjacent to the vascular endodermis are likely to serve as a checkpoint for photoassimilate influx into the inner cortex and, subsequentially, to the bacteroidal tissue.

In conclusion, this work supports the hypothesis that the root nodule is not supplemented by water from xylem. During the LYCH tracing experiments, characteristic differences in depth of diffusion of the dye into root nodules were detected. It should be noted that two barriers for diffusion of low-molecular-weight compounds were found in the root nodules of $M$. truncatula-the nodule endodermis, when nodules were unharmed, and the inner cortex in a case of damaged nodules. Therefore, the study identified three apoplastic domains: the outer cortex, inner cortex and bacteroidal tissue area. The results showed the existence of symplastic continuity between sieve elements and the first layer of the parenchyma cells. We postulate that these cells play a pivotal role in transportation of photoassimilates to the nodule interior as well as in influencing the activation of the oxygen diffusion barrier.

Open Access This article is distributed under the terms of the Creative Commons Attribution License which permits any use, distribution, and reproduction in any medium, provided the original author(s) and the source are credited.

\section{References}

Abd-Alla MH, Koyro HW, Yan F, Schubart S, Peiter S (2000) Functional structure of the indeterminate Vicia faba L. root nodule: implication for metabolite transport. J Plant Physiol 157:335-343

Ade-Ademilua OE, Botha CEJ (2006) What Does the Movement of the Phloem-mobile Symplamic Tracer 5,6-carboxyfluorescein in Shoots of Pisum sativum L. Indicate-the Existence of a Symplasmic Transport System?-A bid to Answer Some Puzzling Questions. Am J Plant Physiol 1:127-131

Baluska F, Samaj J, Hlavacka A, Kendrick-Jones J, Volkmann D (2004) Actin-dependent fluid-phase endocytosis in inner cortex cells of maize root apices. J Exp Bot 396:463-473

Brown SM, Walsh KB (1994) Anatomy of the Legume Nodule Cortex with Respect to Nodule Permeability. Aust J Plant Physiol 21:49-68

Brown SM, Walsh KB (1996) Anatomy of the Legume Nodule Cortex: Species Survey of Suberisation and Intercellular Glycoprotein. Aust J Plant Physiol 23:211-225

Brown SM, Chudek JA, Hunter G, Sprent JI, Walsh KB, Wurtrz G (1997) Proton density and apoplastic domains within soybean nodules in relation to the oxygen diffusion barrier. Plant Cell Environ 20:1019-1029

Complainville A, Brocard L, Roberts I, Dax E, Sever N, Sauer N, Kondorosi A, Wolf S, Oparka K, Crespi M (2003) Nodule Initiation Involves the Creation of a New Symplasmic Field in Specific Root Cells of Medicago Species. Plant Cell $15: 2778-2791$ 
Fahraeus G (1957) The Infection of Clover Root Hairs by Nodule Bacteria Studied by a simple Glass Slide Technique. J Gen Microbiol 16:374-381

Fisher DG (1988) Movement of Lucifer Yellow in leaves of Coleus blumei Benth. Plant Cell Environ 11:639-644

Fisher DG, Oparka KJ (1996) Post-pholem transport: principles and problems. J Exp Bot 47:1141-1154

Frazer HL (1942) The occurrence of endodermis in leguminous root nodules and its effect on nodule function. Proc R Soc Edinb 61:328-343

Guinel FC (2009) Getting around the legume nodule: I. The structure of the peripheral zone in four nodule types. Botany 87:1117-1138

Hillmer S, Quader H, Robert-Nicoud M, Robinson DG (1989) Lucifer Yellow uptake in cells and protoplasts of Daucus carota visualized by laser scanning microscopy. J Exp Bot 40:417-423

Hillmer S, Hedrich R, Robert-Nicoud M, Robinson DG (1990) Uptake of Lucifer Yellow $\mathrm{CH}$ in leaves of Commelina communis is mediated by endocytosis. Protoplasma 158:142-148

Hirsch A (1992) Developmental biology of legume nodulation. New Phytol 122:211-237

Jones KM, Kobayashi H, Davies BW, Taga ME, Walker GC (2007) How rhizobial symbionts invade plants: the Sinorhizobium-Medicago model. Nat Rev Microb 5:619-633

Kramer EM, Frazer NL, Baskin TI (2007) Measurment of diffusion within the cell wall in living roots of Arabidopsis thaliana. J Exp Bot: 3005-3015

Lalonde S, Tegeder M, Throne-Holst M, Frommer WB, Patrick JW (2003) Phloem loading and unloading of sugars and amino acids. Plant Cell Environ 26:37-56

Lemoine R (2000) Sucrose transporters in plants: update on function and structure. Biochim Biophys Acta 1456:246-262

Marzec M, Kurczynska EU (2008) Symplasmic communication/ isolation and plant cell differentiation. Adav in Cell Biol 35:369-389

Massou S, Albigot R, Prats M (2000) Carboxyfluorescein fluorescence experiments. Biochem Edu 28:171-173

Oldroyd GED, Geurts R (2001) Medicago truncatula, going where no plant has gone before. Trends Plant Sci 6:552-554

Oparka KJ (1991) Uptake and compartmentation of fluorescent probes by plant cells. J Exp Bot 42:565-579
Oparka KJ, Prior DAM (1988) Movement of Lucifer Yellow CH in potato tuber storage tissues: A comparison of symplastic and apoplastic transport. Planta 176:533-540

Owen TP, Platt-Aloia KA, Thomson WW (1991) Ultrastructural localization of Lucifer Yellow and endocytosis in plant cells. Protoplasma 160:115-120

Parsons R, Day DA (1990) Mechanism of soybean nodule adaptation to different oxygen pressures. Plant Cell Environ 13:501-512

Pradel KS, Ullrich CI, Santa Cruz S, Oparka KJ (1999) Symplastic continuity in Agrobacterium tumefaciens-induced tumors. J Exp Bot 50:183-192

Schulze J (2004) How are nitrogen fixation rates regulated in legumes? J Plant Nutr Soil Sci 167:125-137

Stewart WW (1981) Lucifer dyes-highly fluorescent dyes for biological tracing. Nat 292:17-21

Stougaard J (2000) Regulators and regulation of legume root nodule development. Plant Physiol 124:531-540

Streeter G (1993) Translocation-A key factor limiting the efficiency of nitrogen fixation in legume nodules. Physiol Plant 87:616-623

Sujkowska M, Górska-Czekaj M, Bederska M, Borucki W (2011) Vacuolar organization in the nodule parenchyma is important for the functioning of pea root nodules. Symbiosis 54:1-16

Terpolilli JJ, O'Hara GW, Tiwari RP, Dilworth MJ, Howieson JG (2008) The model legume Medicago truncatula A17 is poorly matched for N2 fixation with the sequenced microsymbiont Sinorhizobium meliloti 1021. New Phytol 179:62-66

Tucker JE, Mauzerall D, Tucker EB (1989) Symplastic transport of caroxyfluorescein in stamina hairs of Setcresea purpurea is diffusive and includes loss to the vacuole. Plant Physiol 90:1143-1147

Vasse J, de Billy F, Camut S, Truchet G (1990) Correlation between ultrastructural differentiation of bacteroids and nitrogen fixation in alfalfa nodules. J Bacteriol 172:4295-4306

Vernie T, Moreau S, de Billy F, Plet J, Combier J, Rogers C, Oldroyd G, Frugier F, Niebel A, Gamas P (2008) EFD IS an ERF Transcription factor involved in the control of nodule number and differentiation in Medicago truncatula. Plant Cell 20:2696-2713

Walsh KB, McCully ME, Conny MJ (1989) Vascular transport and soybean nodule function: nodule xylem is a blind alley, not a throughway. Plant Cell Environ 12:395-405

White J, Prell J, James EK, Poole P (2007) Nutrient sharing between symbionts. Plant Physiol 144:604-614 